\title{
ANÁLISE TEMPORAL DO CRESCIMENTO DO SÍTIO URBANO DE GARANHUNS-PE E SUAS CONSEQUÊNCIAS AMBIENTAIS
}

\author{
Felippe Pessoa de Melo
}

\author{
José Antônio Pacheco de Almeida
}

RESUMO: O presente trabalho tem como objetivo analisar o crescimento urbano em Garanhuns-PE e suas consequências geoambientais. A mancha urbana de Garanhuns-PE vem crescendo de maneira desordenada no transcorrer das últimas décadas, provocando diversos problemas ambientais. Para compreender esse fenômeno geográfico foi realizada uma análise temporal de 1982 a 2010, das consequências ambientais do processo de expansão do sítio urbano, tendo-se como subsídio para análise e compreensão dessa problemática as tecnologias do Sensoriamento Remoto e SIG. Diagnosticou-se que o processo de expansão urbana em direção às áreas de encostas está ocorrendo com a finalidade de fixação de moradias ou para prática de atividades agrárias de subsistência, sendo que ambas as atividades ocorrem sem contemplar os princípios do desenvolvimento sustentável.

Palavras chave: Sustentável. Problemas ambientais. Tecnologias.

\section{INTRODUÇÃO}

A expansão urbana desordenada é um problema comum na região nordeste do Brasil; suas origens estão ligadas ao êxodo rural. No estado de Pernambuco esse fenômeno representa um problema frequente, mas nas últimas décadas maximizou-se, principalmente nas cidades que atuam como polos regionais.

Em Garanhuns-PE esse fenômeno intensificou-se com a construção de espaços residenciais afastados do centro comercial da cidade para as comunidades de baixa 


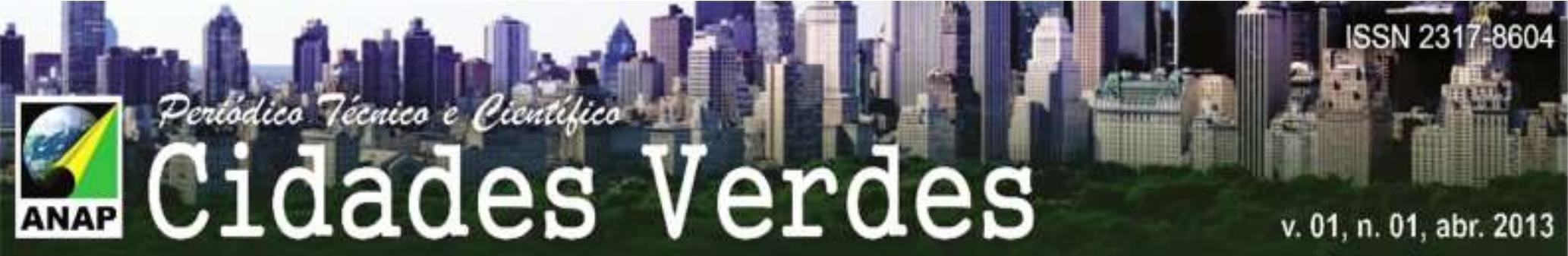

renda (COHABS I, II e III, Várzea, Manoel Xeu, Bela Vista, Parque Fênix, Liberdade, Massaranduba, Vale do Mundaú, São Carlos, Mãe Rainha...) e conjuntos residenciais fechados em locais melhores localizados, para classe social de maior poder aquisitivo (Garoa, Úrsula Moraes, Morada do Sol, Alamedas da Serra, Monteverde, Vale do Una...).

O avanço em direção às encostas não está levando em consideração as peculiaridades topográficas do modelado, o qual tem como principal característica um modelado ondulado em forma de colinas. Esse modelo de uso e ocupação do solo está provocando diversos problemas de ordens ambientais e econômicas no espaço geográfico. Dentre eles destacam-se: movimentos de massas, lixiviamento do solo, retirada da cobertura vegetal nativa, implantação de flora exótica, falta de saneamento ambiental, contaminação dos corpos de água.

É necessário compreender que o modelado onde está situada a cidade de Garanhuns apresenta peculiaridades geológicas, geomorfológicas, biogeográficas e climáticas que devem ser levadas em consideração na ampliação do assentamento urbano. Dessa forma, os problemas geoambientais causados e agravados ao longo do processo de ampliação do perímetro urbano podem ser minimizados, tendo como consequência direta a maximização da qualidade de vida da população, principalmente daquela que ocupa as áreas mais críticas, tendo em conta os princípios do desenvolvimento sustentável. Sendo assim, o presente trabalho tem como objetivo analisar o crescimento urbano em Garanhuns-PE e suas consequências geoambientais.

\section{MATERIAIS E MÉTODOS}

\subsection{MATERIAIS}

Para a realização da pesquisa, os materiais foram empregados conforme a necessidade de cada método aplicado. Portanto utilizou-se: teses, artigos científicos e livros que contemplam a problemática socioambiental da área em questão; dados SRTM, do projeto Brasil em Relevo da EMBRAPA, com as seguintes características técnicas: formato GeoTiff / 16 bits, resolução espacial de 90m, sistema de coordenadas geográficas e datum WGS-84, correspondente à carta digital SC-24-X-B; imagens via satélite da DGI 
do INPE, obtidas através dos satélites: Landsat 5 equipado com o sensor TM que apresenta a resolução espacial de 30m. (as imagens são referentes aos anos: 1985, 1987, 1990, 1999 e 2010 e CBERS 2B, equipado com o sensor HRC que possui uma resolução espacial de 2,7m, referentes aos anos de 2007, 2008, 2009 e 2010); arquivos vetoriais da CPRM, referentes às cartas digitais SC-24-X-B-VI e SC-24-X-B-V; fotografias aéreas do INCRA, na escala de 1:5.000 (1982); planta base do município, na escala de 1:15:000 (1982); folha SC-24-X-B-V da SUDENE, com a escala de 1:100.000 (1986); carta SC-24-X-B-VI da SUDENE, na escala de 1:100.000 (1986); arquivos shp e pdf, do IBGE; imagens do Banco de Dados Geomorfométricos do Brasil, Projeto Topodata, com a articulação 1:250.000, formato GeoTiff, cena 08S375; GPS e o SIG SPRING.

\subsection{MÉTODOS}

Foi criado um banco de dados geográfico georreferenciado contendo as informações provenientes da pesquisa de gabinete.

Posteriormente foi realizada uma pesquisa de campo com a finalidade de confirmar, corrigir e preambular as informações provenientes da pesquisa de gabinete.

Em seguida foram realizadas as análises e interpretações do material para posterior confecção das cartas temáticas.

\section{CARACTERIZAÇÃO DA ÁREA}

A cidade está localizada na Região Nordeste do Brasil, no Planalto da Borborema, na Mesorregião do Agreste e na Microrregião Garanhuns, estando delimitada pelos paralelos de $8^{0} 51^{\prime} 37^{\prime \prime} / 8^{0} 55^{\prime} 40^{\prime \prime} \mathrm{S}$ e pelos meridianos de $36^{\circ} 26^{\prime} 6^{\prime \prime} / 36^{\circ} 30^{\prime} 52^{\prime \prime} \mathrm{W}$ (Figura 01). 

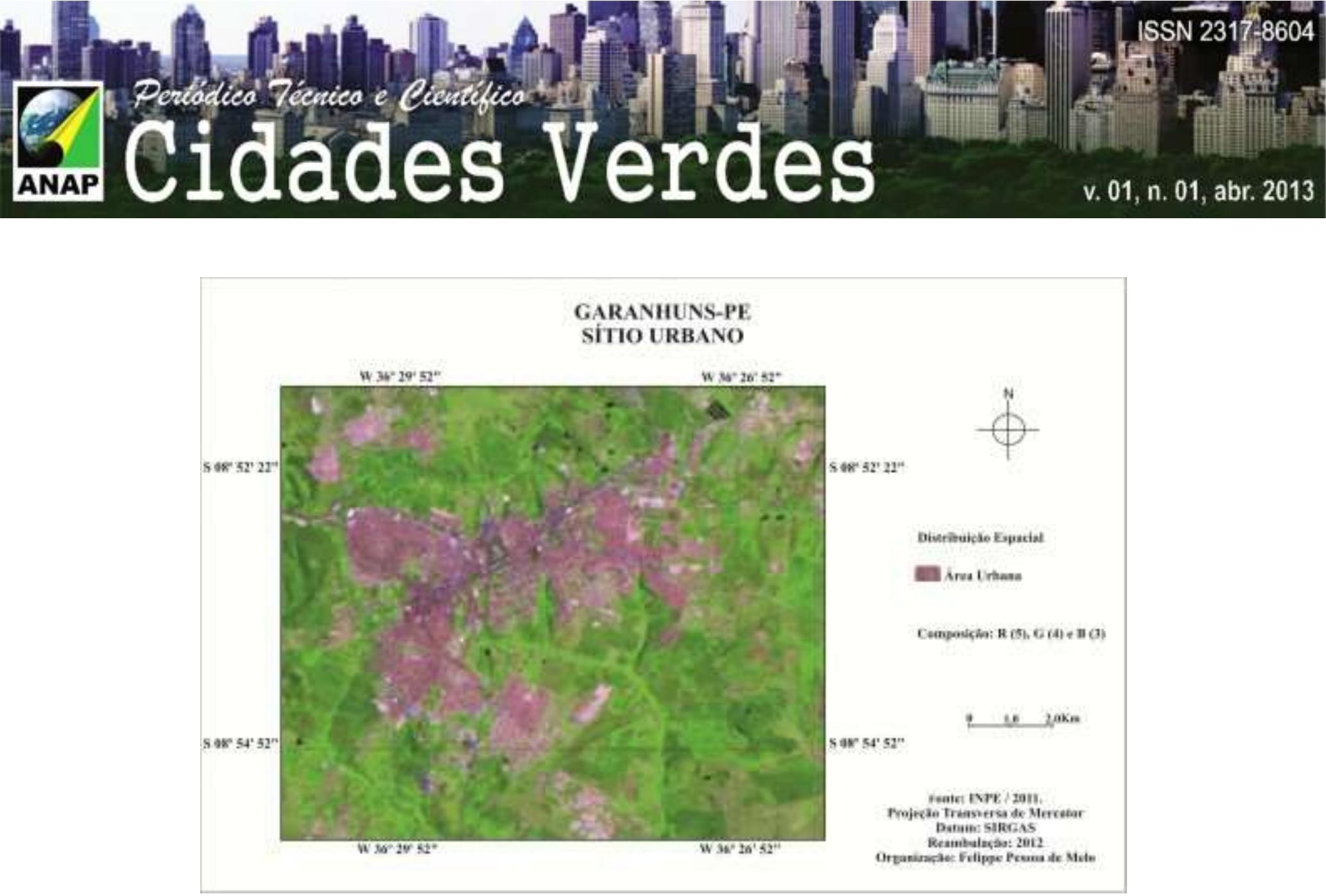

Figura 01 - Distribuição espacial do perímetro urbano.

\subsection{ASPECTOS FISIOGRÁFICOS}

O município apresenta valores hipsométricos que oscilam de 725 a mais de $954 \mathrm{~m}$ (Figura 02). Nessa topografia destacam-se: as superfícies somitais convexas com uma área de $3,57 \mathrm{Km}^{2}$, na qual o morro denominado Magano representa $17,55 \%$ dessas feições e possui o ponto mais alto da cidade $(1.030 \mathrm{~m})$ estando localizado nas coordenadas de 8 52' 42" S e 36 31' 6" W; estruturas aplainadas com uma área de $14,37 \mathrm{Km}^{2}$, dos quais $22,41 \%$ são descontínuos; dois níveis distintos de dissecação do modelado, o primeiro tem uma área de $23,62 \mathrm{Km}^{2}$ e o segundo $22,94 \mathrm{Km}^{2}$ e vales com uma dimensão total de $10,64 \mathrm{Km}^{2}$. 

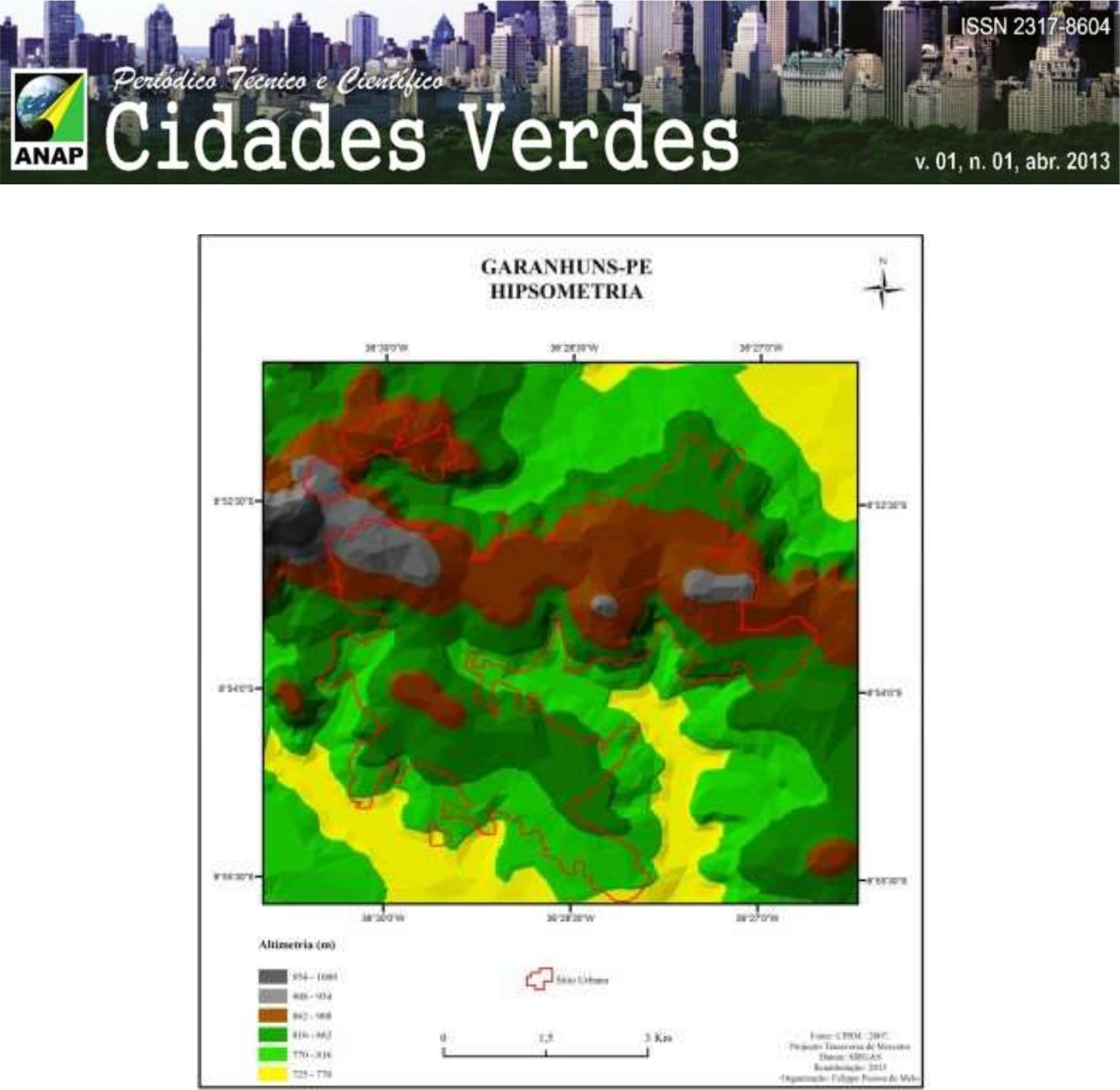

Figura 02 - Características topográficas.

As peculiaridades topográficas e sua localização na porção oriental do Planalto da Borborema possibilita a Garanhuns-PE ter o clima Mesotérmico Tropical de Altitude, colocando-o em uma posição de destaque em relação aos sistemas climáticos do nordeste brasileiro, sofrendo a influência da ZCIT durante os meses de março e abril e da FPA durante o outono e inverno (Gráfico 01).

A precipitação média anual é $80,1 \mathrm{~mm}$, com máxima de $155,8 \mathrm{~mm}$ em junho e 
mínima de $23 \mathrm{~mm}$ em novembro. Seu período mais chuvoso vai de março a agosto, com uma precipitação média de 118,5mm. O período com menor índice pluviométrico ocorre de setembro a fevereiro com uma pluviometria média de 41,61mm.

A média térmica anual é de $21,7^{\circ} \mathrm{C}$. Durante o inverno a média térmica é $19,1^{\circ} \stackrel{ }{ } \mathrm{C}$. As temperaturas podem atingir $14,1^{\circ} \mathrm{C}$. A mais fria registrada foi $9^{\circ} \mathrm{C}$ em 1961 . No verão a média térmica é de $34,4^{\circ} \mathrm{C}$, com máxima de $35,4^{\circ} \mathrm{C}$. Os intervalos de tempos mais frios ocorrem a partir das dezesseis horas até ás nove horas do dia seguinte.

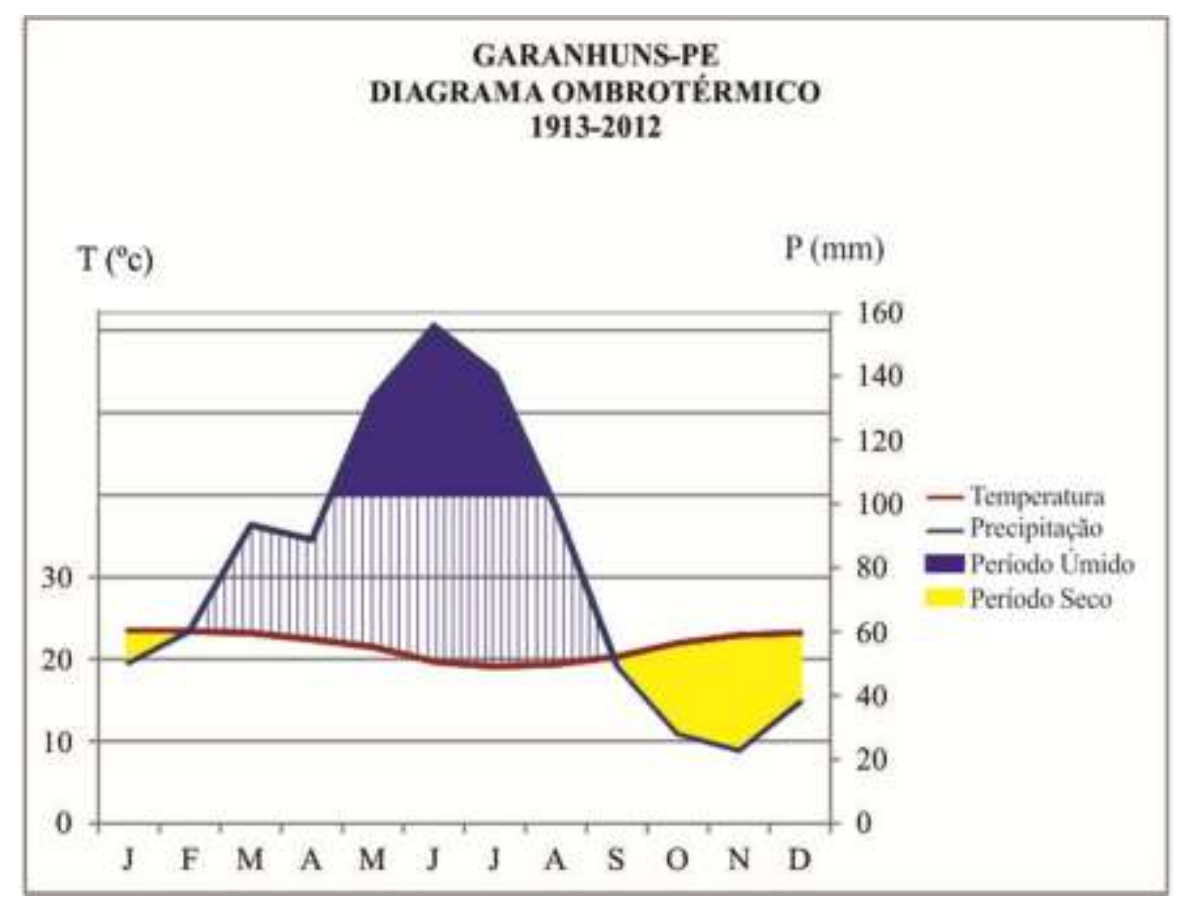

Gráfico 01 - Relação entre temperatura e precipitação.

\subsection{GEOLOGIA}

Ao regionalizar o local da pesquisa destacam-se os complexos denominados de Cabrobó e Belém de São Francisco (Figura 03). O primeiro é constituinte de uma sequência clástica ou vulcano-sedimentar continental, onde está assentado o perímetro urbano de Garanhuns-PE; e o segundo refere-se à área circunvizinha, caracterizando-se 


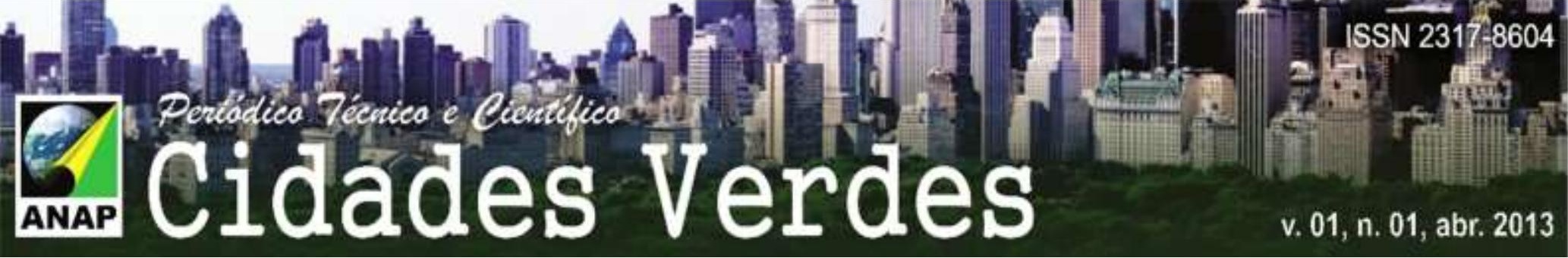

pela presença de ortognaisses e migmatitos com restos de supracrustais. O complexo Cabrobó é subdividido em quatro unidades.

O sítio urbano de Garanhuns-PE está totalmente inserido na unidade dois do complexo (Figura 04), o qual possui a presença de: biotita gnaisse, biotita xisto, migmatito, mármore, muscovita-biotita xisto, muscovita-biotita gnaisse, metagrauvaca e metarcóseos. E está sobre a influência geológica das unidades: Caetés, Conceição, Ibirajuba, Rio Una 2 e 3, Saloá, Serra da Caatinga Branca e Serrote dos Macacos.

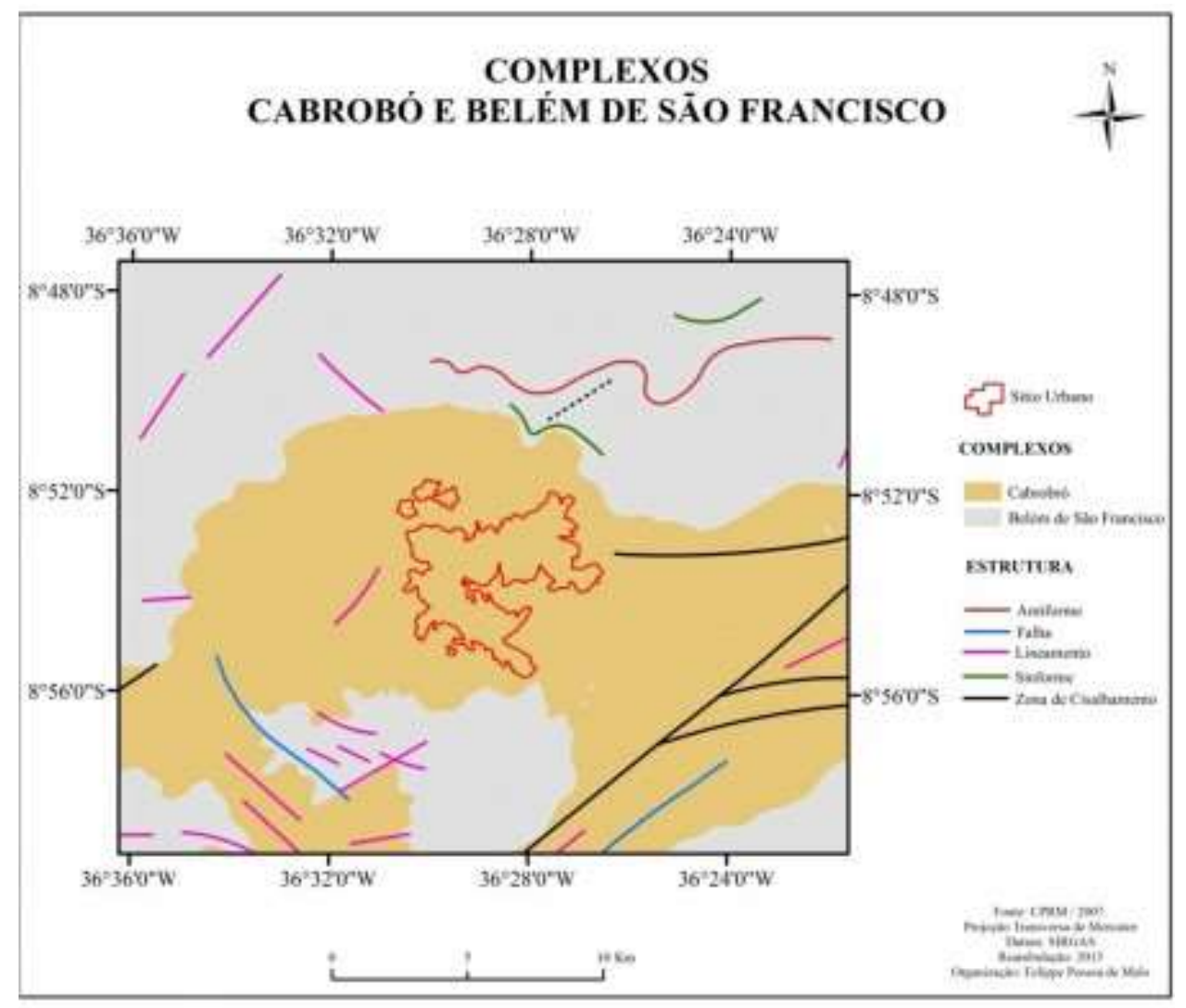

Figura 03 - Complexos regionais. 

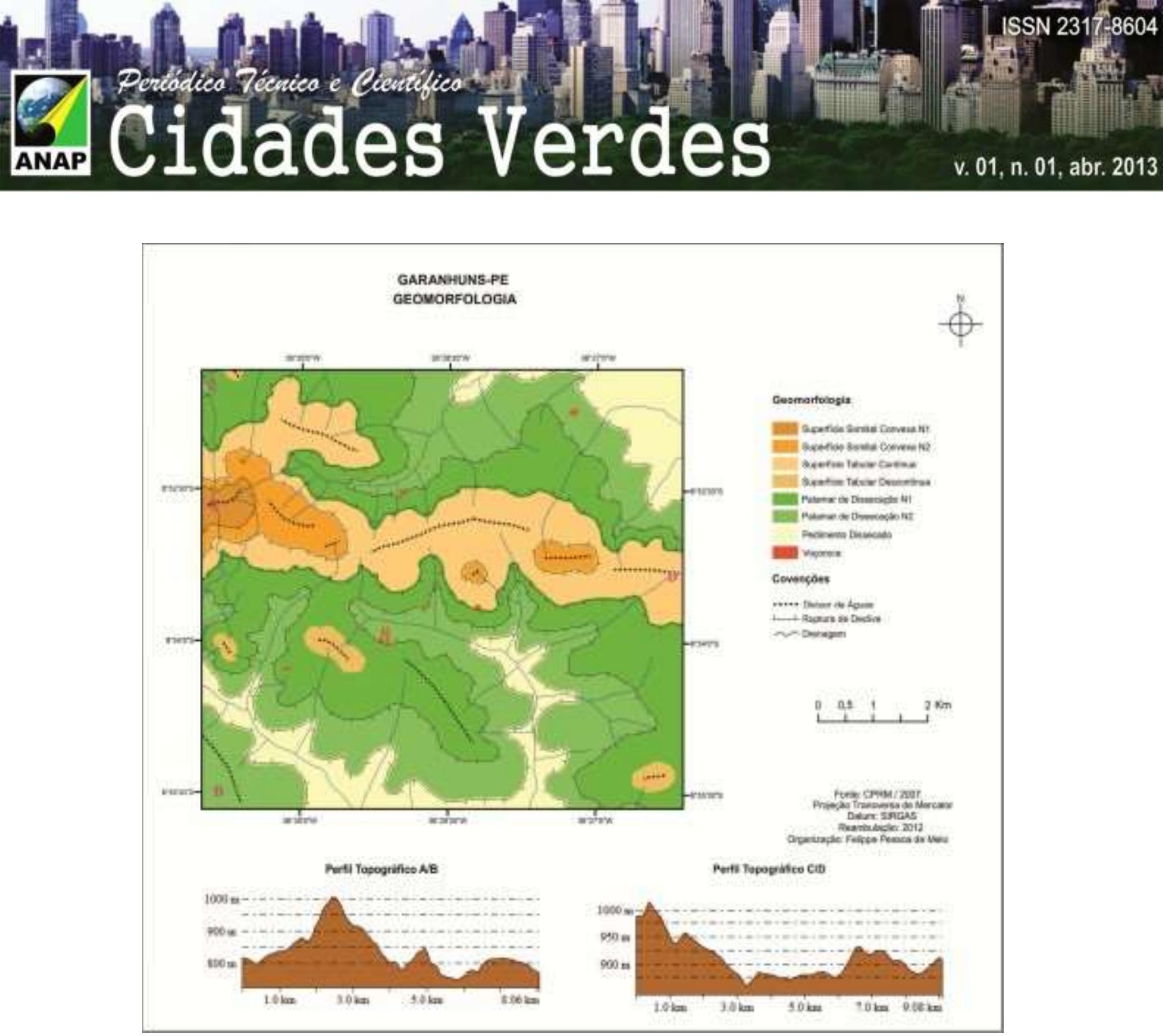

Figura 05 - Características geomorfológicas.

\subsection{REDE HIDROGRÁFICA}

O município está inserido na Bacia Hidrográfica do Mundaú. Essa rede hidrográfica está localizada nos Estados de Pernambuco e Alagoas, abrangendo uma área de 4.090,39 km² dos quais 2.154,26 km² estão no Estado de Pernambuco, correspondendo a $2,19 \%$ do seu território. A porção compreendida no território 
pernambucano se encontra delimitada pelos paralelos 08ㄴ 41' 34" / 09 14' $00^{\prime \prime} \mathrm{S}$ e pelos meridianos de 360' $36^{\prime \prime}$ / 36우 37' 27' W.

Limita-se com: Bacia do Rio Una (norte), Estado de Alagoas e um grupo de rios secundários (sul), Bacia do Rio Una e o Estado de Alagoas (leste) e Bacia do Rio Una (oeste). A referida drenagem abrange 15 municípios (Caetés, Garanhuns, Canhotinho, Lagoa do Ouro, Brejão, Calçado, Capoeiras, Jucati, Jurema, Jupi, Lajedo, Angelim, Correntes, Palmeirina e São João).

O Rio Mundaú nasce em Garanhuns, sendo seus principais afluentes: Riacho Conceição, Riacho Salgado, Rio Correntes, Rio Mundauzinho e o Rio Canhoto.

\section{USO E OCUPAÇÃO DO SOLO}

\subsection{ATIVIDADES ECONÔMICAS LOCAIS E CONSEQUÊNCIAS AMBIENTAIS}

A criação de gado de corte e leiteiro com a finalidade de abastecer o mercado interno e as demais cidades do Estado de Pernambuco, o cultivo de monoculturas como o algodão e o café com as mesmas finalidades da atividade anterior, produção de carvão vegetal para atender a demanda interna das panificadoras, extração de madeira com o objetivo de fazer fogueiras para que as mesmas sejam revendidas local e regionalmente, atendendo o mercado dos festejos juninos, abertura de loteamentos residenciais, foram as principais atividades que contribuíram para retirada da vegetação nativa.

O conjunto dessas atividades ao longo das décadas culminou em um cenário urbano sem a infraestrutura necessária para atender os setores da economia e as necessidades da população, destacando-se a falta de: saneamento ambiental, áreas de lazer, local adequado para tratamento dos resíduos residenciais, comerciais e industriais, inchaço do centro comercial devido à hipervalorização imobiliária. Esse modelo de desenvolvimento territorial é insustentável, e suas consequências já são visíveis ao longo da paisagem (Figura 6). 

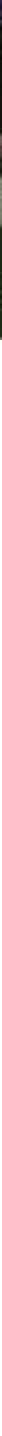

Figura 06 - Solo lixiviado.

\subsection{FLORA EXÓTICA}

A cidade encontra-se localizada no ecótono Zona da Mata - Sertão do nordeste brasileiro, por isso originalmente apresentava em sua flora uma vasta variedade de espécies, sendo que atualmente só existem resquícios dessa cobertura vegetal. O Parque Ruber van der Linden, por exemplo, possui exemplares dessa flora. Sistematicamente essa flora foi sendo retirada para que ocorresse o aumento do espaço geográfico urbano.

Mas a falta de cobertura vegetal nas porções urbanas está maximizando a absorção do calor, o que provoca uma sensação térmica desconfortável na população, tendo os habitantes de baixa renda como protagonistas. Isso porque as características estruturais de suas casas apresentam uma série de problemas, destacando-se: paredes baixas e conjugadas, falta de espaço para circulação do vento entre as casas, telhados sem o devido isolamento térmico, construções irregulares... 


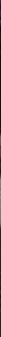

Assim, visando minimizar a sensação de calor e melhorar a estética da paisagem, introduziu-se a flora exótica na localidade. As principais espécies introduzidas foram o Pinheiro-do-Paraná (Araucaria angustifolia), Castanhola (Terminalia catappa), Espécies de Eucaliptos (Eucalyptus), Nim da Índia (Azadirachta indica).

Atualmente o Nim da Índia é a variedade que possui a maior aceitação pela população, por apresentar um índice de crescimento que oscila entre 4 e $7 \mathrm{~m}$ nos primeiros anos, o que é bem mais rápido que o das espécies nativas. Sua copa pode atingir até $12 \mathrm{~m}$, seu tronco é quase retilíneo e pode chegar aos $20 \mathrm{~m}$. Possui um sistema radicular que pode chegar aos $15 \mathrm{~m}$ de profundidade, o que facilita sua sobrevivência em períodos com escassez de água. Essas são as principais características que levam a população a optar por essa árvore.

Levando em consideração que as casas das comunidades pobres apresentam calçadas com uma média 1,5m de largura, o plantio dessa árvore vai ocasionar um problema na estrutura dessas casas em um intervalo temporal bem curto.

\subsection{ANÁLISE ESPAÇO-TEMPORAL DO CRESCIMENTO URBANO}

Ao realizar a análise e interpretação da expansão urbana em Garanhuns verificase que em 1982 o sítio urbano era concentrado em uma área longitudinal contínua com $7,64 \mathrm{~km}^{2}$. Entre 1982 e 1987 o perímetro urbano cresceu 1,94km², ampliando-se de maneira mais expressiva nos sentidos nordeste e sudoeste. Nos intervalos temporais 1987 / 1995 a mancha urbana teve um acréscimo de $1,52 \mathrm{~km}^{2}$, novamente com grande ênfase para as porções nordeste e sudoeste, ocorrendo um pequeno crescimento descontínuo a noroeste, com a formação de uma porção urbana descontínua de $0,15 \mathrm{~km}^{2}$ chamada de COHAB III. Entre 1995 e 2001 ocorreu uma desaceleração no ritmo de crescimento, inchando $1,9 \mathrm{~km}^{2}$, destacando-se a porção nordeste e sudoeste.

No período de 2001 a 2011, o perímetro urbano desenvolveu-se $6,5 \mathrm{~km}^{2}$, principalmente nas áreas nordeste, sudoeste e noroeste. No extremo noroeste esse fenômeno fica bem evidenciado com o incremento de $0,38 \mathrm{~km}^{2}$ na COHAB III através do Programa Minha Casa Minha Vida, para atender a comunidade de baixa renda removida 


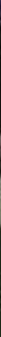

do Vale da Liberdade pelos órgãos competentes e o surgimento do condomínio de luxo Bellevue - Residencial Clube com uma área de $0,25 \mathrm{~km}^{2}$.

O estudo multitemporal da área em questão facilita a compreensão do arranjo espacial e suas consequências geoambientais (Figura 07).

Figura 07 - Ritmo de crescimento urbano.

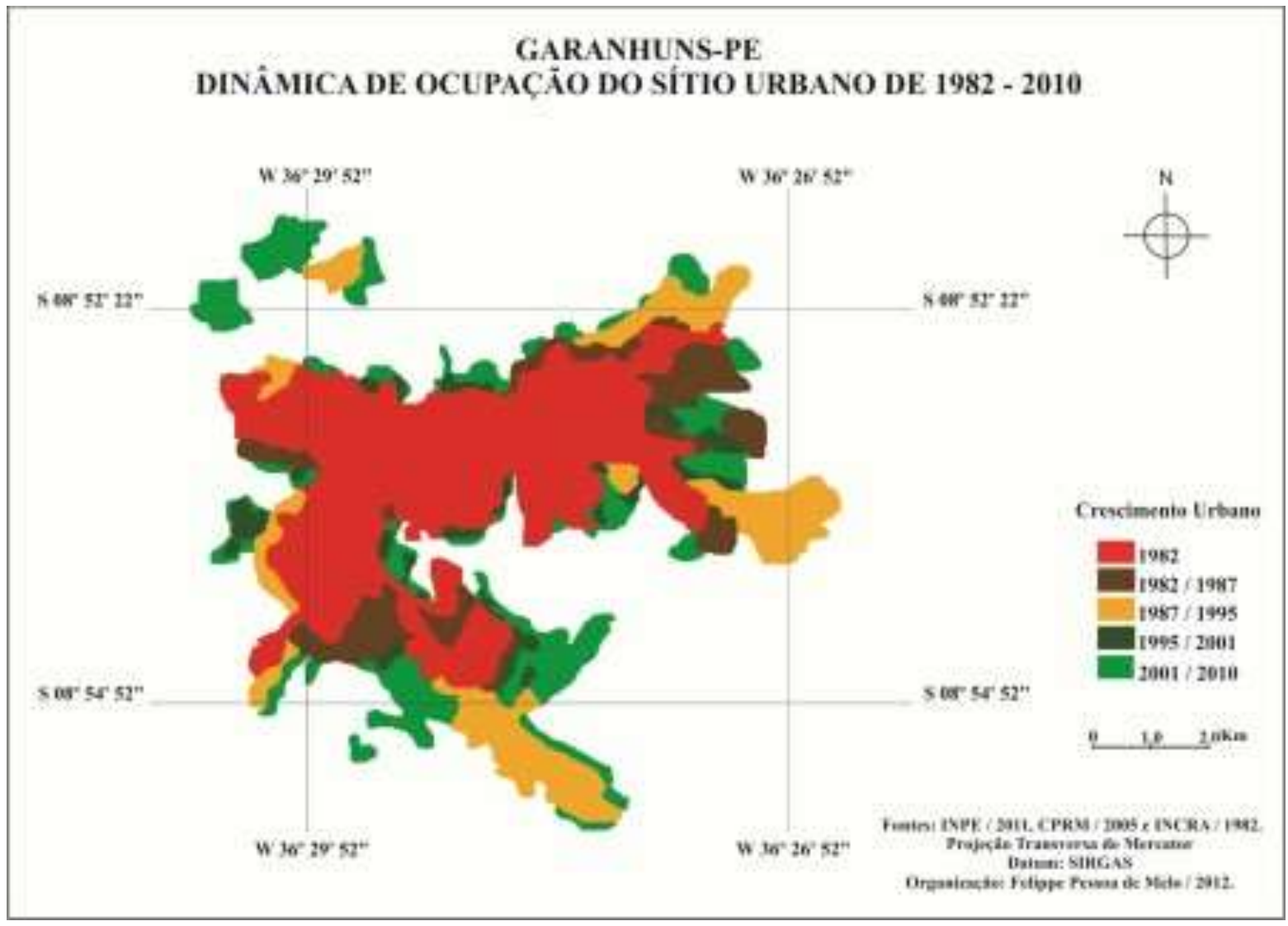

\section{AV ANÇO URBANO EM DIREÇÃO ÀS ENCOSTAS}

Esses processos ocorrem naturalmente no relevo, sendo que as características do modelado podem proporcionar uma maior ou menor velocidade. No caso do sítio urbano de Garanhuns-PE, essas transformações ocorrem de forma mais rápida, devido suas peculiaridades físicas (Figura 08) e pela ação antrópica (Figura 09). 

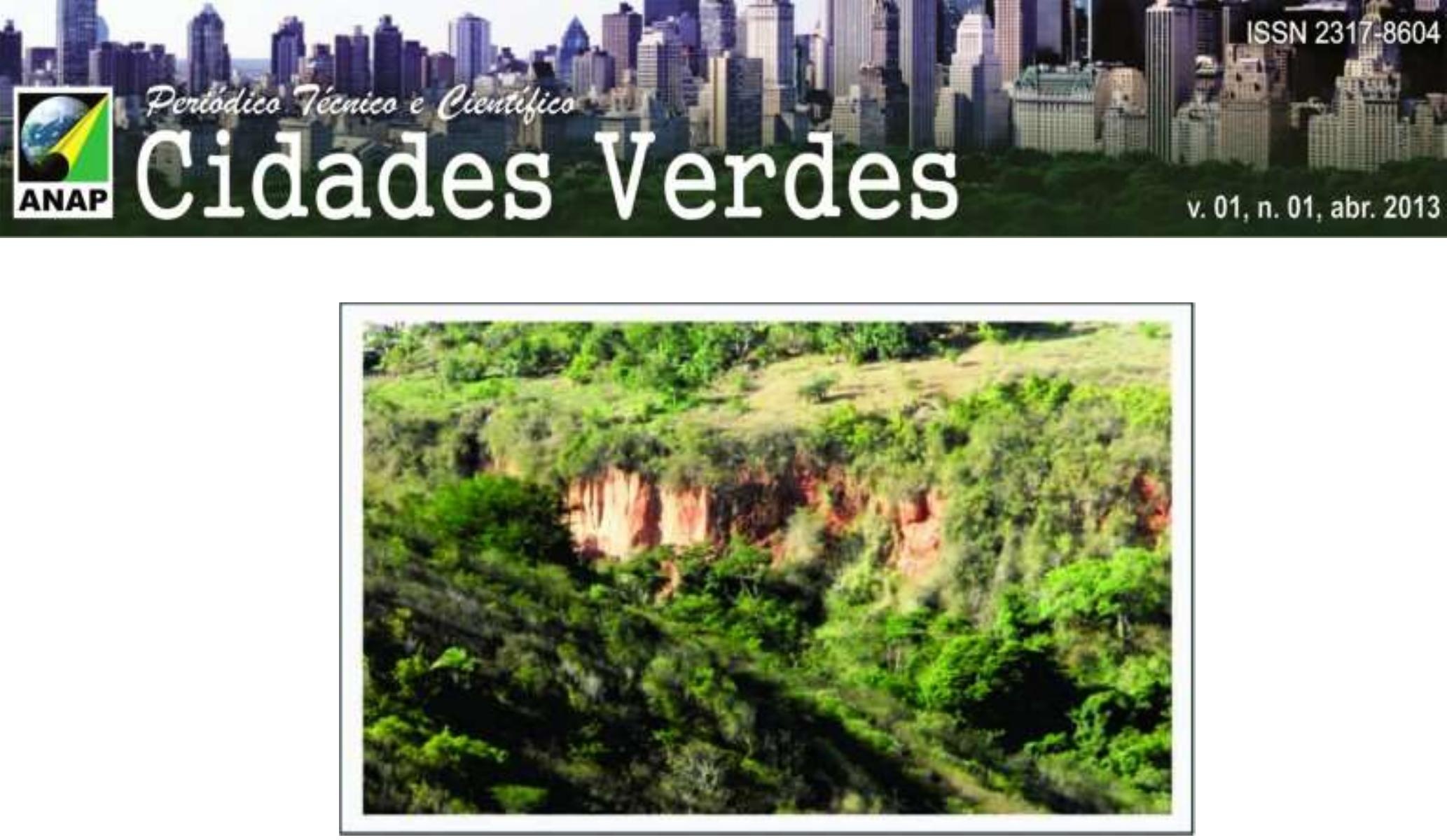

Figura 08 - Desmoronamento de encosta de vale.

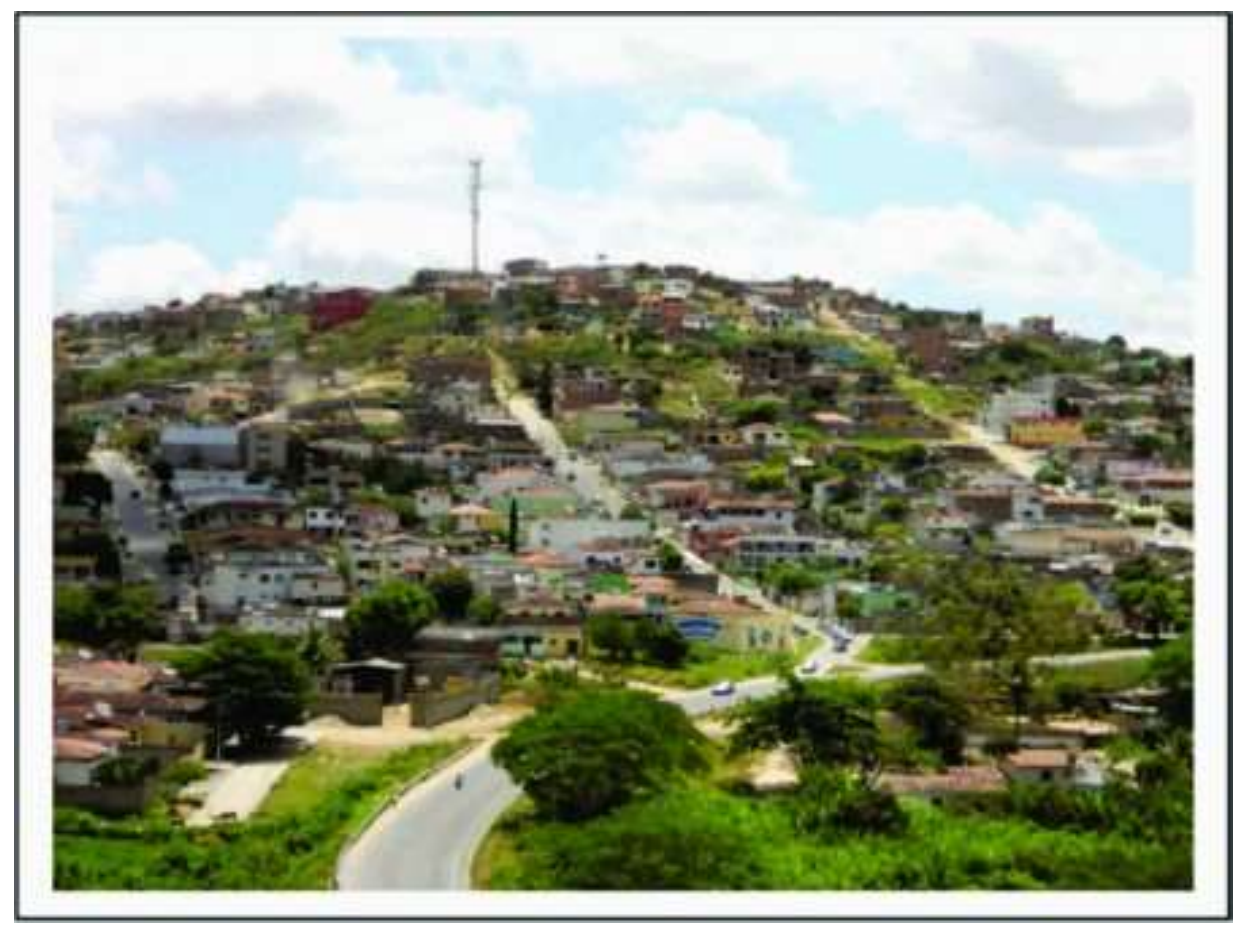

Figura 09 - Processo de urbanização desordenada.

As características físicas que atuam de maneira mais determinantes são: relevo ondulado em forma de colinas (devido o grau de inclinação de suas vertentes, favorece o 


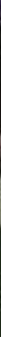

movimento gravitacional descendente); clima Cs'a (favorecendo o intemperismo químico); tipos de solos (no perímetro urbano ocorrem dois tipos de solos (Latossolos e Podzólicos) que tem como característica comum o baixo percentual de corpos rochosos) e a rede hidrográfica (os corpos de água temporários e permanentes tem suas capacidades erosivas ampliadas devido ao grau de inclinação das vertentes).

Em relação à atuação humana, os fenômenos que operam de maneira mais contundente são: desmatamento (favorece a ação erosiva); drenagem urbana (o sistema de esgotos não é adequado para as peculiaridades do modelado) e o crescimento urbano desordenado (não respeitando a capacidade temporal de recuperação do meio natural). Os elementos de caráter geomorfológicos ou parâmetros topográficos que tratam das relações entre o modelado e drenagem permanente ou temporária, que ocorrem nas encostas, englobam: declividade, forma da encosta, tipo de solo, simetria dos vales... Associando esses parâmetros às condições climáticas, retirada da cobertura vegetal $\mathrm{e}$ urbanização, tem-se um quadro de desequilíbrio geoambiental.

A intensa ação antrópica nessas feições do modelado sem os devidos cuidados, em conjunto com suas peculiaridades estruturais maximizam os processos que levam a desestruturação desse tipo de feição (Figura 10).

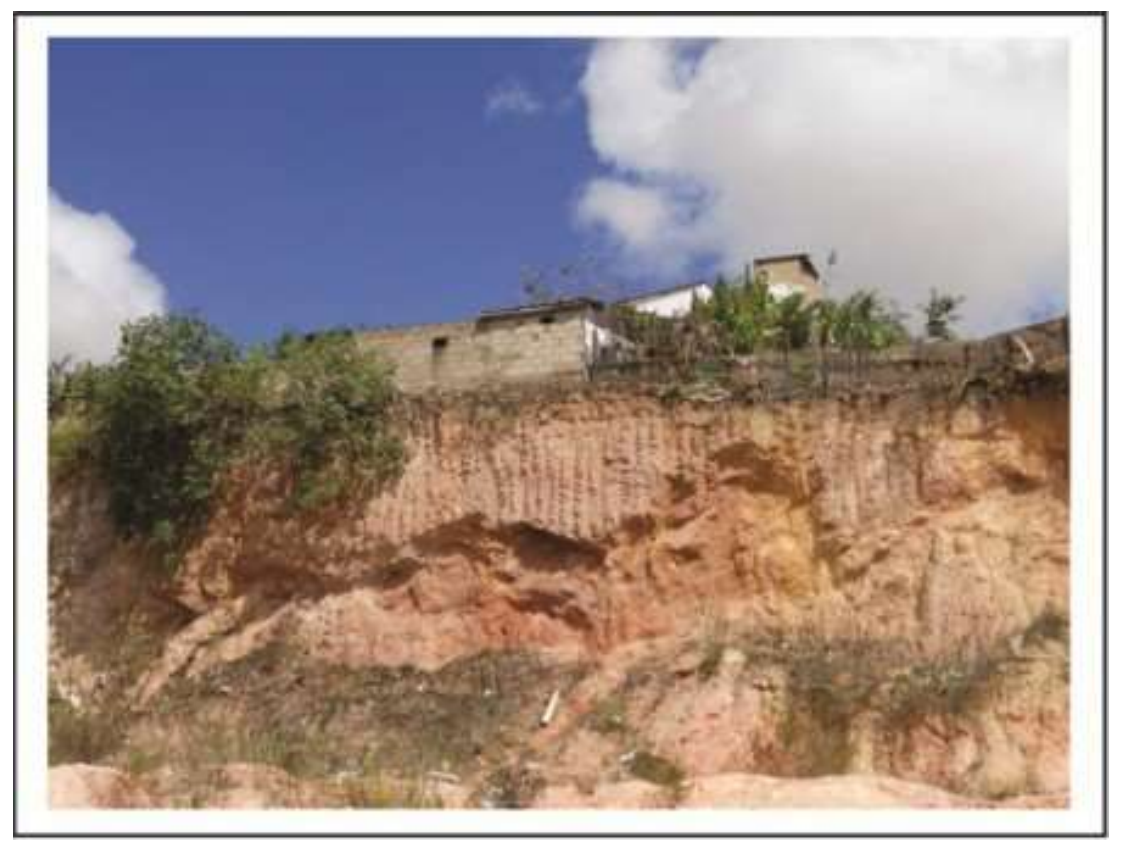

Figura 10 - Desmoronamento em área residencial. 


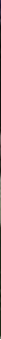

O arranjo morfoestrutural do modelado em questão naturalmente já é bem susceptível a processos erosivos (Figura 11), não sendo necessária a presença de fluxos de águas contínuos. Nesse contexto a erosão que mais se destaca no espaço geográfico do sítio urbano de Garanhuns é a acelerada ou antrópica, confirmando a intensa ação antrópica sobre as estruturas do modelado, sem levar em consideração as peculiaridades geográficas do relevo.

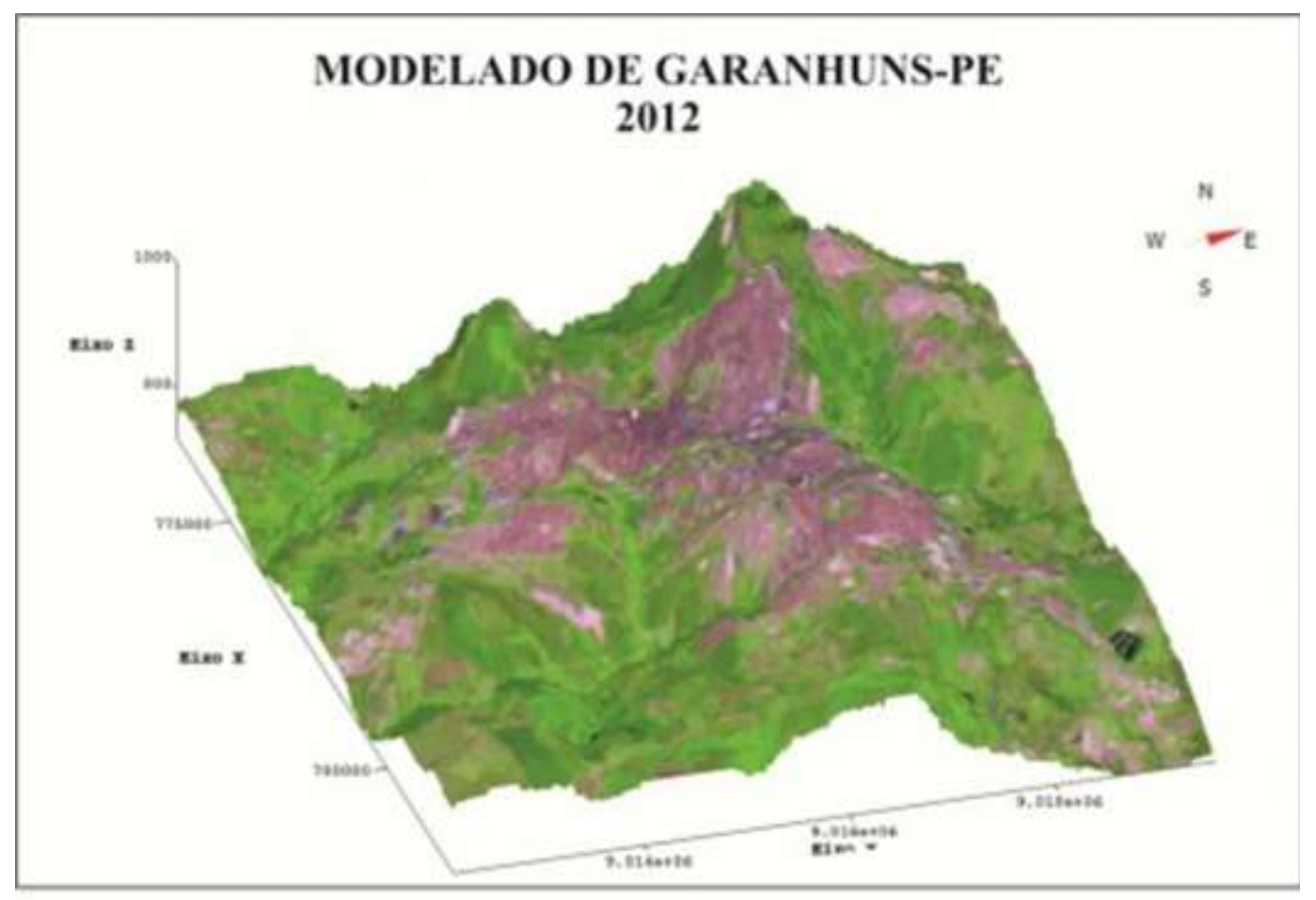

Figura 11- Modelado em 3D.

A realização de cortes nas vertentes para facilitar o processo de ocupação está desconsiderando a drenagem temporária e permanente do relevo, forçando esses corpos de água a se encaixarem em novos cursos. No caso em questão eles estão se encaixando nas ruas íngremes do espaço urbano, o que maximiza a capacidade erosiva desses corpos de água. 


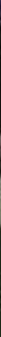

A água exerce um grande poder sobre e dentro do solo, com grande relevância nos processos de transporte. Assim um solo pode estar ou não saturado.

Em um solo saturado à água há uma grande pressão sobre os grãos o que leva a afastarem-se uns dos outros; porém, quando o solo não está saturado suas partículas apresentam um maior grau de agregação.

No espaço urbano de Garanhuns não se encontra rochas aflorando. Com isso suas encostas são cobertas por solo ou regolito derivados principalmente do intemperismo químico.

O conjunto dessas transformações no modelado provoca uma reestruturação na distribuição espacial da população, sendo que a classe de renda mais baixa tende a fixar residência nas porções mais instáveis das feições geomorfológicas (Figura 12).

Paralela a essa ocupação começam a praticar atividades agrícolas de subsistência, como o plantio da banana (Musa sapientum) nas encostas do vale localizado entre os bairros Heliópolis e Liberdade (Figura 13).

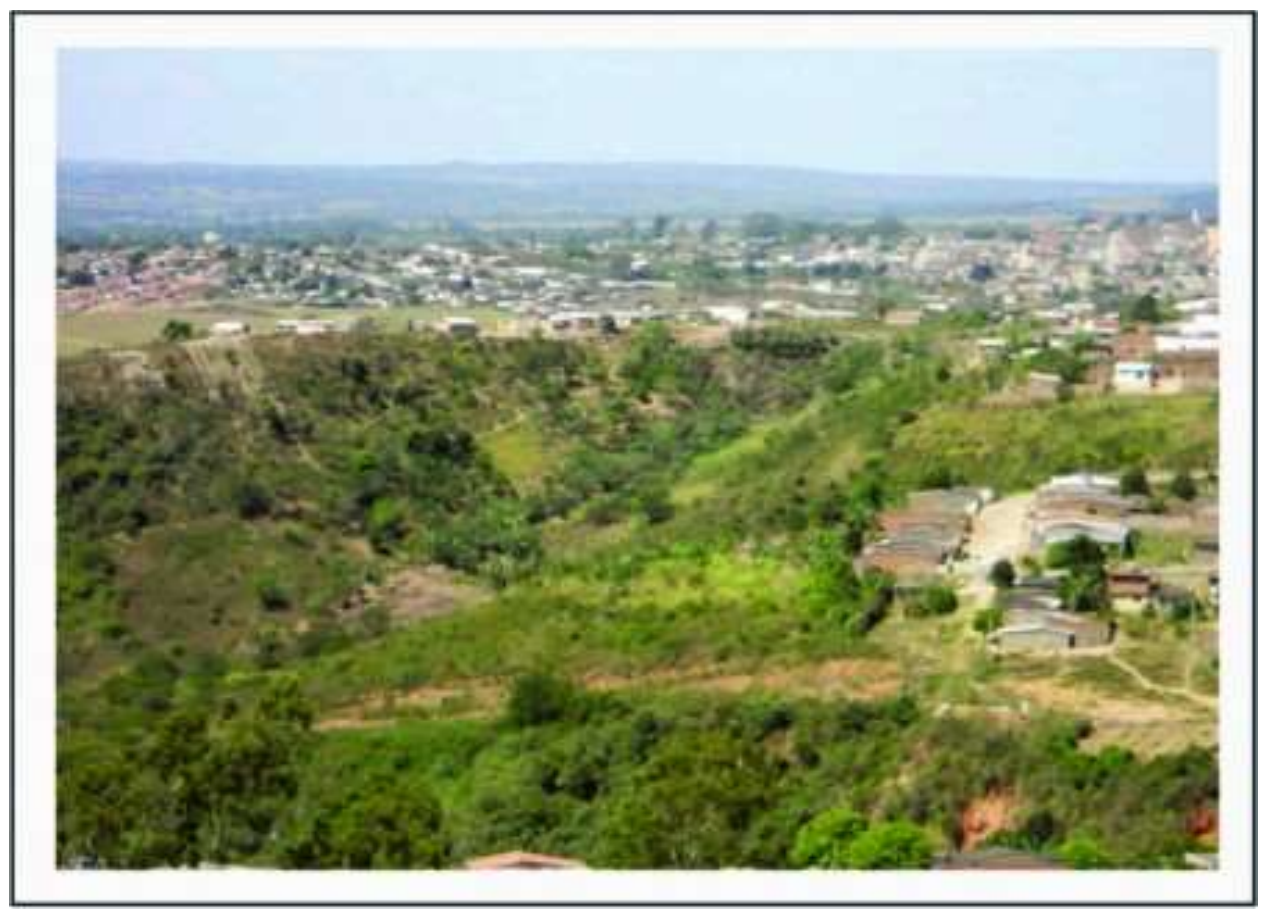

Figura 12 - População Ocupando as Bordas Instáveis de um Vale. 

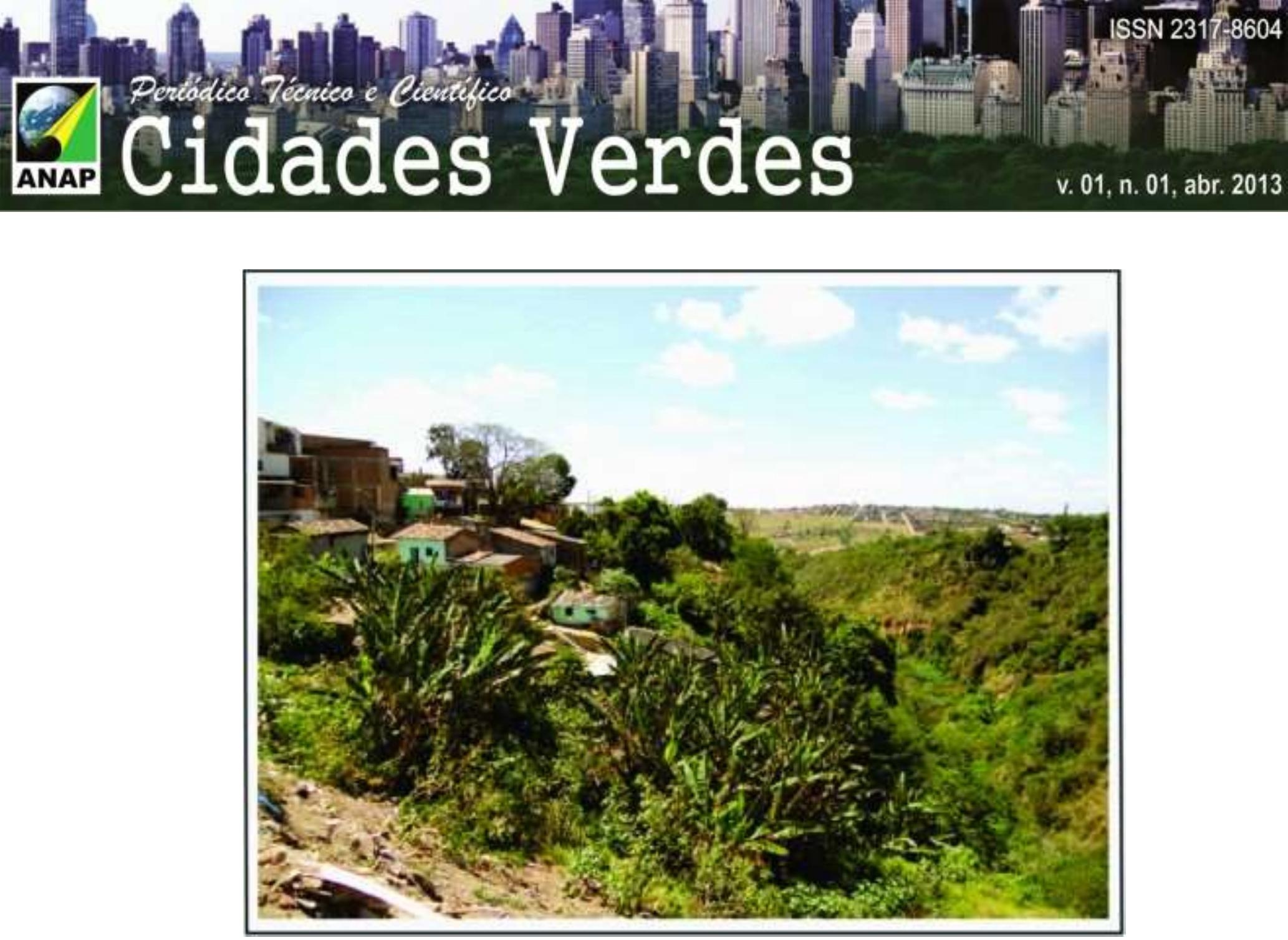

Figura 13 - Agricultura de subsistência

Esse tipo de prática agrícola nesse ambiente desestabiliza o solo, tornando-o mais susceptível a deslizamentos e desmoronamentos. Para tentar controlar esses processos são despejados restos de materiais oriundos da construção civil nas áreas com maior sensibilidade aos agentes erosivos. Mas essas medidas são apenas paliativas; quando chega a estação chuvosa os movimentos de massas se intensificam, colocando a população em risco.

As porções mais abertas dos vales são aproveitadas para realização da pecuária extensiva, reaproveitando as águas dos esgotos sem o devido tratamento como fonte de água permanente para o gado. Essa drenagem encaixa-se em áreas esculpidas por cursos de águas temporários ou permanentes. 


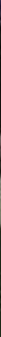

Esse tipo de prática provoca doenças de veiculação hídrica no gado, o qual será abatido para o consumo da população, podendo vir a provocar problemas como disenteria, giardíase, hepatite $A$, cólera, febre tifoide...

Para minimizar os impactos da rede hidrográfica urbana no modelado, os órgãos governamentais realizam obras de infraestrutura, mas eles não levam em consideração as peculiaridades físicas do local, contribuindo para problemas estruturais nessas obras (Figura 14) e agravando os movimentos de massas no perímetro (Figura 15).

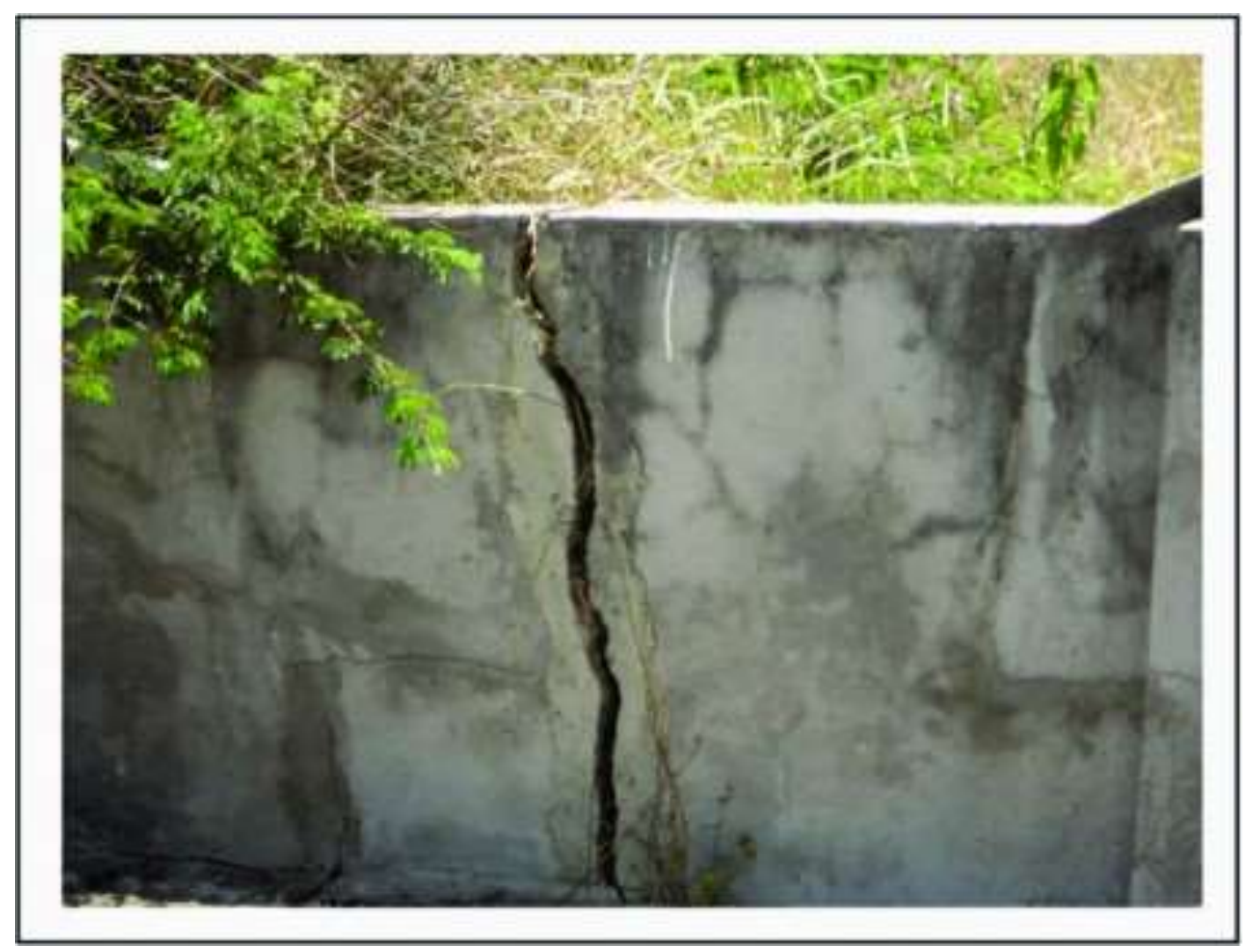

Figura 14 - Estrutura comprometida. 

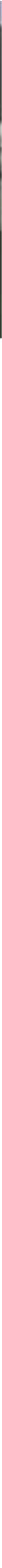

Figura 15 - Movimentos de massas.

Outra prática comum nas áreas de expansão do sítio urbano são as queimadas. Essa atividade acelera os processos erosivos provocando a desestruturação dos solos. Os problemas provenientes do crescimento urbano em direção as áreas de encostas, podem ser minimizados através de um planejamento urbano que leve em consideração os aspectos físicos do modelado, proporcionando sua ocupação de forma sustentável. Os movimentos de massas na zona urbana de Garanhuns são responsáveis por uma grande quantidade de problemas de ordem social, econômica e ambiental.

\section{LOCALIZAÇÃO DAS ÁREAS DE RISCO}




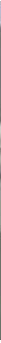

Dentro desse cenário de risco geoambiental (Figura 16), destacam-se as comunidades: Liberdade, Heliópolis, Novo Heliópolis, Parque Fênix, COHAB III, São José, Barreira do Inferno, Santo Antônio, Jardim Petrópolis e Magano.

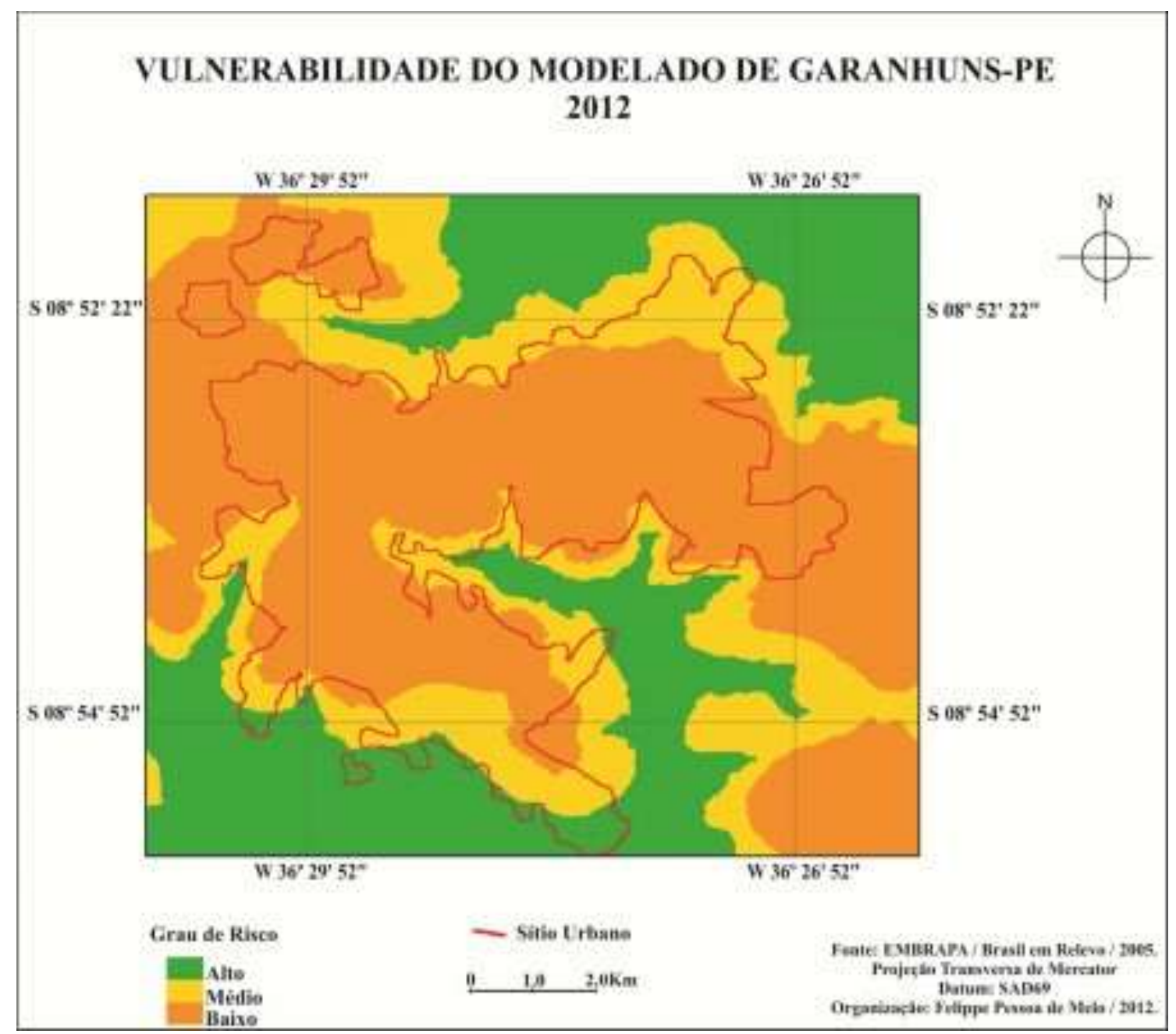

Figura 16 - Potencial de Risco de Movimentos de Massas.

A comunidade da Liberdade está instalada na borda leste do vale da liberdade popularmente chamado de buracão. As encostas dessa área estão desestabilizadas devido a retirada da cobertura vegetal nativa para ampliação do perímetro urbano sem a competente infraestrutura. O sistema de esgoto dessas casas é estruturado de maneira que os dejetos orgânicos são armazenados em fossas individuais ou coletivas nas 


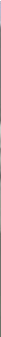

encostas ou são jogados diretamente nas vertentes. Em ambos os modelos de descarte dos resíduos o geoambiente é prejudicado com a contaminação e saturação do solo. As porções mais íngremes das vertentes que não são ocupadas com moradias são aproveitadas para realização de atividades agrárias com ênfase para o cultivo de banana, feijão, milho, criação de animais de pequeno porte, como galinhas, cabras, suínos... O fundo do vale é ocupado com o mesmo modelo agrícola acima exemplificado e com a criação de gado de corte e leiteiro. O modelo de ocupação do espaço geográfico implantado por essa comunidade provoca interferências na topografia local que maximizam a capacidade dos agentes erosivos. Aplicando a classificação de Filho (1992) para movimentos de massas, constata-se que os quatro processos são visivelmente encontrados na localidade em questão. Em 2010 a população que ocupava a área mais crítica dessas encostas foi removida pela Defesa Civil e alocada na COHAB III. Logo em seguida essas moradias foram destruídas para evitar uma nova ocupação, sendo que essa localidade não foi contemplada com procedimentos que possibilitassem sua recuperação ambiental.

O Heliópolis é um bairro que ocupa a borda oeste do vale da liberdade. Seu modelo de uso e ocupação do espaço geográfico ocorre de maneira mais estruturada, pois a população que ocupa essa localidade é de alto poder aquisitivo. Seu esgoto é contemplado com um canal que recebe seus dejetos residenciais, o que evita que eles sejam despejados nas encostas do vale, porém essas águas não são tratadas e são despejadas no fundo do vale, provocando problemas de contaminação no solo. Suas fossas sépticas são bem estruturadas e estão longe de corpos de água, entretanto as casas que estão localizadas nas margens das encostas instalam suas fossas nas proximidades da vertente ou despejam seus dejetos diretamente no sistema de esgoto público. Devido sua infraestrutura, as casas localizadas nessa porção do modelado não apresentam processos erosivos intensos. Apenas as casas que estão mais próximas da vertente é que apresentam movimentos de massas suaves, do tipo rastejo ou creep.

O bairro Novo Heliópolis ocupa as bordas leste e oeste de um vale, sendo que ambas as margens são contempladas com um sistema de esgoto o que minimiza os problemas nas encostas, mas contamina os solos do fundo do vale. Logo, essas águas 


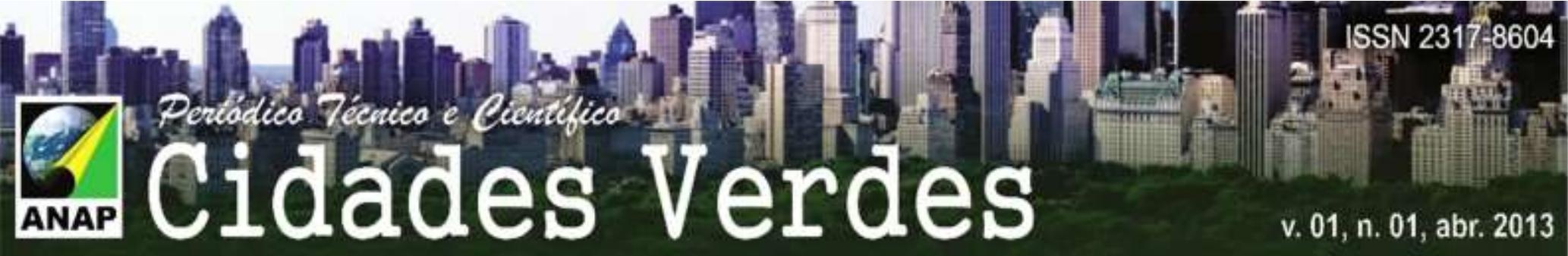

são despejadas sem tratamento. As casas que estão localizadas nas encostas e próximas a esse sistema de esgoto público despejam seus dejetos diretamente nele; as demais possuem fossas sépticas individuais. Devido a melhorias na infraestrutura dessa área, ela está passando por um processo de valorização imobiliária, tendo como consequência a retirada da cobertura vegetal secundária para a abertura de novos loteamentos. Essas ações estão desestabilizando as encostas das feições. As moradias que estão mais próximas dessa área já começam a apresentar rachaduras devido ao rastejo ou creep.

A comunidade do Parque Fênix ocupa o lado leste do vale do Novo Heliópolis, a qual está com um processo da flora local bem avançado. Seu esgoto é despejado diretamente nas vertentes desestabilizando as encostas, contaminando os solos... As residências que estão mais afastadas das encostas possuem fossas sépticas individuais ou coletivas. Em relação aos movimentos de massas nessas feições, destacam-se os escorregamentos e corridas. Devido à abertura de novos lotes na porção noroeste do bairro, ocorreu o processo de desaceleração do processo de urbanização em direção as vertentes.

A COHAB III está situada na porção norte de um vale. Devido a falta de um sistema de saneamento adequado os esgotos são despejados nas margens das vertentes, provocando a desestabilização e contaminação dos solos com os dejetos residenciais. As moradias localizadas nas encostas quando não despejam seus dejetos diretamente nessas feições, possuem fossas sépticas artesanais mal estruturadas, as quais, quando enchem, não são esgotadas com os devidos cuidados. Ao analisar as casas que estão próximas ou nas encostas, nota-se que apresentam rachaduras por causa do rastejo ou creep. No perímetro do bairro encontra-se a presença de sulcos e ravinas encaixados dentro da drenagem oriunda das residências.

O bairro São José apresentava-se como uma área de baixo risco em relação a movimentos de massas em encostas, mas como o processo de construção de prédios residenciais nessa área está ocorrendo de forma inadequada, suas vertentes começam apresentar quedas ou falls. Para maximizar as áreas de ocupação estão sendo feitos cortes retilíneos e escalonados nas encostas. Sem levar em consideração as 


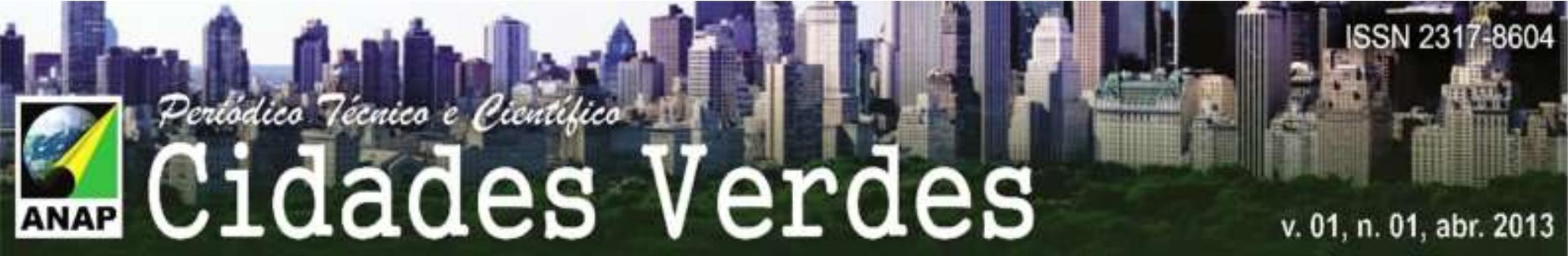

das nascentes do Rio Mundaú. A princípio essa água é aproveitada para criação de gado e para lavar roupas na lavanderia pública municipal.

\section{CONCLUSÕES}

O processo de assentamento e ampliação do sítio urbano de Garanhuns-PE não levou em consideração questões políticas e religiosas, desconsiderando as peculiaridades físicas e capacidade de recuperação do geoambiente, o que maximizou a ação dos agentes erosivos, fenômenos como lixiviamento, assoreamento, formação de sulcos, ravinas, voçorocas, deslizamentos e desmoronamentos, corpos de água contaminados, que são de fácil percepção na paisagem.

Utilizando as tecnologias do sensoriamento remoto e SIG para formação de um banco de dados geográfico digital foi possível realizar a interpolação dessas informações, o que possibilitou a confecção dos mapas temáticos necessários (Hipsométrico, Solos, Geológico, Geomorfológico, Drenagem, Dinâmica de Uso e Ocupação do Solo e Vulnerabilidade do Modelado) para analisar e interpretar as relações e consequências do modelo de ocupação do espaço geográfico no espaço temporal de 1982 a 2010.

Com base nessas informações foram localizadas no modelado da área em questão dez principais zonas de risco para população (Liberdade, Heliópolis, Novo Heliópolis, Parque Fênix, COHAB III, São José, Barreira do Inferno, Santo Antônio, Jardim Petrópolis e Magano) devido ao alto nível de instabilidade das encostas, as quais são ocupadas por residências, utilizadas para práticas econômicas de subsistência (agricultura familiar, criação de animais de pequeno e médio porte, retirada de argila para olarias...), descarga do esgoto urbano sem o devido tratamento, aproveitado para descarte de resíduos sólidos, cortadas para ampliar o espaço do lote... O conjunto dessas ações insustentáveis está promovendo alterações nas feições e contaminação dos corpos de água, os quais, em sua maioria, são utilizados para o consumo humano e animal. 


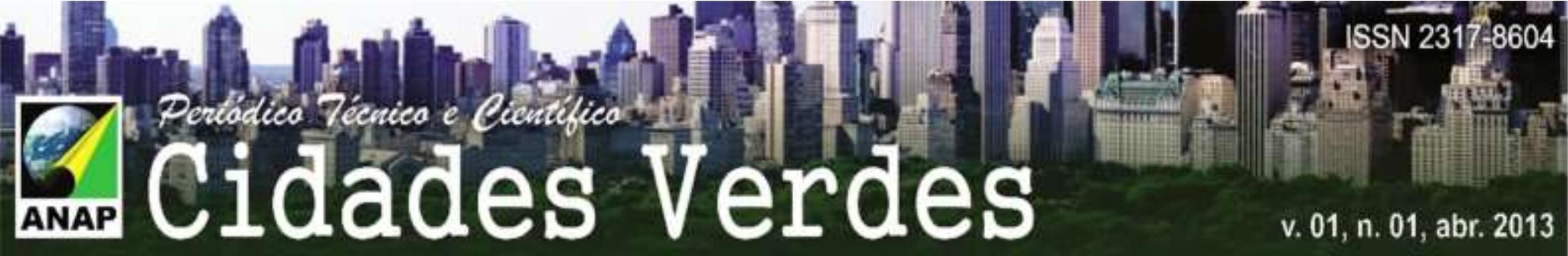

O poder público tenta amenizar essa situação com a construção de obras paliativas emergenciais esporádicas (construção de muros de contenção, ampliação da rede de esgoto, remoção temporária ou permanente da população que ocupa locais com maior probabilidade de deslizamentos ou desmoronamentos...), mas elas surtem pouco efeito nessa dinâmica socioespacial. Já as comunidades tentam minimizar a instabilidade das encostas colocando restos de detritos da construção civil, medida que apenas minimiza temporariamente o problema, já que essa feição não apresenta cobertura vegetal para estabilizá-la. Para os habitantes, o ápice desses problemas ocorre nos meses mais chuvosos que vão de abril a julho, intervalo temporal que apresenta uma precipitação média de 118,25mm. Esse alto índice pluviométrico, encharca as encostas desprotegidas e instáveis agravando ainda mais esse cenário.

Para minimizar os impactos geoambientais no sítio urbano de Garanhuns-PE é necessária a implantação de um modelo de uso e ocupação do solo sustentável, possibilitando, incentivando e subsidiando ações como: pesquisas sobre a morfodinâmica local e suas relações com o sítio urbano, recuperação das áreas verdes com flora local, substituição do saneamento básico pelo saneamento ambiental, alternativas econômicas para as comunidades mais carentes, remanejamento da população das áreas para locais seguros...

Para que essas medidas tenham os efeitos desejados é necessário que ocorram de forma conjunta entre a sociedade, o poder público e a comunidade acadêmica, evitando assim que elas ocorram de maneira inadequada, o que as tornaria pouco eficazes. Um bom exemplo foi o remanejamento de uma parte da população da comunidade da Liberdade para a COHAB III, porquanto nessa ação ocorreu apenas a transferência parcial da população, ou seja, o perímetro da encosta instável não foi recuperado nem monitorado. Com isso ele já começa e ser utilizado novamente para atividades econômicas de subsistência e ocupado por pequenas residências.

\section{REFERÊNCIAS}

CPRM-Companhia de Pesquisa de Recursos Minerais. Geobank. Disponível em:

<http://www.cprm.gov.br/>. Acesso em: 21 de abr. 2012.

Cidades Verdes, v.01, n.01, abr. 2013, p. 92 


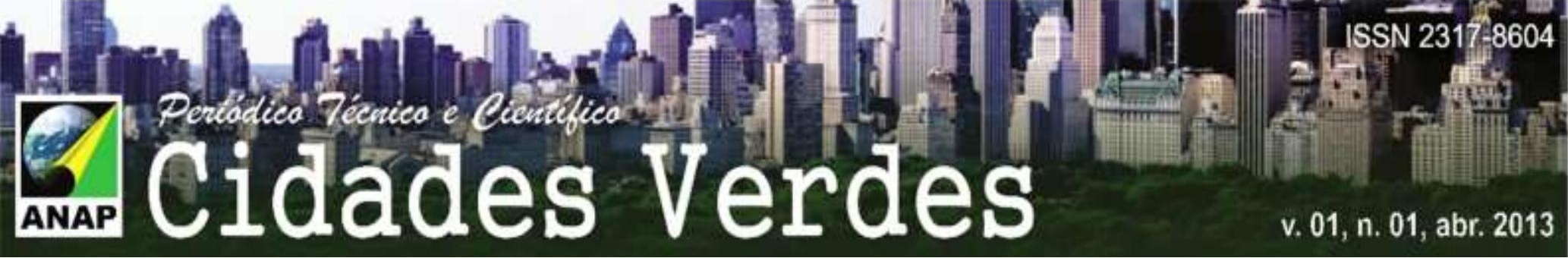

EMBRAPA-Empresa Brasileira de Pesquisas Agropecuárias. Projeto Brasil em Relevo. Disponível em: <http://www.relevobr.cnpm.embrapa.br/download/index.htm>. Acesso em:21 de abr. 2012.

FILHO, A. O. 1992. Escorregamentos em encostas naturais e ocupadas: análise e controle. São Paulo: IPT, p. 96-115. Apostila do curso de geologia de engenharia aplicada a problemas ambientais.

INPE-Instituto Brasileiro de Pesquisas Espaciais. Catálogo de Imagens. Disponível em: <http:// www.dgi.inpe.br/CDSR/>. Acesso em: 20 de jun. 2012.

ROSS, J. L. S. Relevo Brasileiro: uma nova proposta de classificação. Revista do Departamento de Geografia, São Paulo, n. 4, jan./dez. 1985. <http://citrus.uspnet.usp.br/rdg/ojs/index.php/rdg/article/ view/270/251>. Acesso em: 08 jun. 2011. 